\title{
Sustainable Business Models: A Systematic Review of Approaches and Challenges in Manufacturing
}

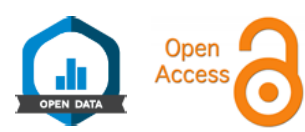

\author{
Modelos de Negócios Sustentáveis: Uma Revisão Sistemática de Abordagens \\ e Desafios na Manufatura
}

\section{ABSTRACT}

Objective: there is an ongoing need for businesses to strive to maintain ideals within environmental, economic, and social values - commonly known as the triple bottom line. Manufacturing as a sector has advanced drastically and the literature on sustainable business models in this sector has emerged. The purpose of this paper is to analyze sustainable business models in manufacturing and the approaches and challenges faced in creating and implementing them. Methods: this paper uses a systematic approach to review the literature. We identify sustainable business models and classify them within different industry areas while strategies and challenges emerge from the literature. Results: the findings indicate that there is some empirical work done in investigating the social and environmental dimensions of sustainability in manufacturing. Overall, there is an ongoing transition to sustainable business models in varying divisions of industry. However, the creation and delivery of sustainable economic value is still unexplored. Conclusions: the research provides insight to researchers and practitioners on how organizations implement sustainability while delivering value to their stakeholders. It also provides new avenues for conducting research in unexplored strategies of sustainable business modeling.

Keywords: sustainable business model; sustainable manufacturing; systematic literature review; sustainability; business model archetypes.
1. UiT The Arctic University of Norway, School of Business and Economics, Tromsø, Norway.

2. University of Stavanger, Centre for Innovation Research, Stavanger, Norway.

Cite as: Agwu, U. J., \& Bessant, J. (2021). Sustainable business models: A systematic review of approaches and challenges in manufacturing. Revista de Administração Contemporânea, 25(3), e200202. https://doi.org/10.1590/1982-7849rac2021200202.en

\section{RESUMO}

Objetivo: há uma necessidade contínua de que as empresas se esforcem para manter os ideais dentro dos valores ambientais, econômicos e sociais comumente conhecidos como triple bottom line. A manufatura como um setor avançou drasticamente e a literatura sobre modelos de negócios sustentáveis neste setor emergiu. $\mathrm{O}$ objetivo deste artigo é analisar modelos de negócios sustentáveis na manufatura e as abordagens e desafios enfrentados na sua criação e implementação. Métodos: este artigo usa uma abordagem sistemática para revisar a literatura. Identificamos modelos de negócios sustentáveis e os classificamos em diferentes áreas da indústria, enquanto estratégias e desafios emergem da literatura. Resultados: os resultados indicam que há algum trabalho empírico realizado na investigaçáo das dimensóes sociais e ambientais da sustentabilidade na manufatura. No geral, há uma transição contínua para modelos de negócios sustentáveis em várias divisóes da indústria. No entanto, a criação e entrega de valor econômico sustentável ainda são inexploradas. Conclusóes: a pesquisa fornece uma visão para pesquisadores e profissionais sobre como as organizaçóes implementam a sustentabilidade e, ao mesmo tempo, agregam valor às suas partes interessadas. Ele também fornece novos caminhos para a realização de pesquisas em estratégias inexploradas de modelagem de negócios sustentável.

Palavras-chave: modelo de negócio sustentável; manufatura sustentável; revisão sistemática da literatura; sustentabilidade; arquétipos do modelo de negócios.

$\stackrel{3}{x}$




\section{INTRODUCTION}

The three-sector theory (Fisher, 1945) and the more recent five-sector model classify manufacturing as a secondary sector of the economy. It comprises "all industrial activities from the customer to the factory and back" (Garetti \& Taisch, 2012, p. 84). Over time, technological improvements have increased efficiency, reduced costs, and enabled mass production. This has brought about industrial growth, which, combined with a growing world population, causes severe side effects to the environment (pollution and resource depletion) and society (invasion of vulnerable populations, child labor, and unfair wages). The manufacturing sector, a bedrock for our civilized way of life, seems to be depleting the resources for the planet and for generations of people it provides for. This sector, although central to the world economy, is long overdue for transformation. Blurred boundaries between sectors have also reinforced this need for transformation. Although the direction of transformation is not exactly clear, there is a notion for action at all levels of the organization (Tonelli, Evans, \& Taticchi, 2013; Willard, 2005) through an overhaul of the traditional business model concept.

The business model concept was once said to have no theoretical grounding in economics and business studies (Teece, 2010). Over time, it has developed clear theoretical roots by anchoring value creation to established theories (Zott \& Amit, 2013). It is linked to efficiency (through transaction costs economics), novelty (through Schumpeterian innovation), complementarities (through resource-based theory), and lock-in (rooted in strategic networks) as a means of creating and delivering value. This is usually done at the detriment of the environment and society. These negative effects have highlighted the importance of participating in the drive for sustainability. The drive has not been limited to firms as individuals; academia and governments are expected to do more than create discussions around the sustainability buzzword. Over the years, there have been calls and pressure (Adams, Jeanrenaud, Bessant, Denyer, \& Overy, 2016; Crals \& Vereeck, 2004; Joyce \& Paquin, 2016) for businesses and organizations to contribute to achieving the most cited definition of sustainable development in the Brundtland report - "development that meets the need of the present without compromising the ability of future generations to meet their own needs" (World Comission on Environment and Development [WCED], 1987, p. 43)

The less cited definition of sustainable development in the Brundtland report states: "In essence, sustainable development is a process of change in which the exploitation of resources, the direction of investments, the orientation of technological development, and institutional change are all in harmony and enhance both current and future potential to meet human needs and aspirations" (WCED, 1987, p. 57). This process of change can be transferred to industry through sustainable business models (SBM). Research (Aagaard, 2019; Bocken, Short, Rana, \& Evans, 2014; Esty \& Winston, 2006; Gupta \& Benson, 2011; Lüdeke-Freund, 2010; Moratis, Melissen, \& Idowu, 2018) has shown that over time, firms can be competitive and sustainable simultaneously. Considering the current sociopolitical state worldwide, reevaluating business models to include sustainability is key to long-term relevance, good moral standing, and profitability.

To advance our understanding of sustainable business models (SBMs), there is emerging literature focusing on industry. Most of them build upon the triple bottom line framework, made popular by Elkington (1994) where economic, social, and environmental values are continuously pursued for the benefits of all stakeholders (Stubbs \& Cocklin, 2008). The literature comprises different approaches to sustainable business models, causing confusion in entities going through this process. Businesses and organizations face a challenge in balancing all three dimensions of sustainability often because actions taken to achieve one form of sustainability affects the others.

Garetti and Taisch (2012) define sustainable manufacturing as smartly "natural resources for manufacturing, creating products and solutions that ... satisfy economic, environmental and social objectives ... while continuing to improve the quality of human life." (Garetti \& Taisch, 2012, p. 85) In practice, this might not be the case. For instance, some manufacturing companies consider environmental compliance as sustainability; others look toward community development or waste reduction. There seems to be a variance on how sustainability is viewed, and a growing number of scholars are developing relevant solutions and frameworks to fit these views.

This study assesses the empirical literature on SBMs in manufacturing processes. Drawing from the business model and sustainability concepts, the aim of this study is to answer the following research question: What is the trend in empirical literature on how different industries in the manufacturing sector implement sustainable business models?

We used the systematic literature review (SLR) approach developed by Adams, Jeanrenaud, Bessant, Denyer and Overy (2016) to map out the reported directions of the empirical literature. It involved three stages as shown in Table 1. 
Table 1. Stages and description of the SLR process.

\begin{tabular}{ll}
\hline \multicolumn{1}{c}{ Stages } & \multicolumn{1}{c}{ Short description } \\
\hline $\begin{array}{l}\text { Stage 1: Developing an initial architecture for reviewing sustainable } \\
\text { business models }\end{array}$ & $\begin{array}{l}\text { Identify, analyze, and synthesize sustainable business models based on the } \\
\text { SBM archetypes }\end{array}$ \\
Stage 2: Systematic review of sustainable business models. & $\begin{array}{l}\text { Using specific databases for literature search, collate the literature using } \\
\text { specified inclusion and exclusion criteria }\end{array}$ \\
Stage 3: Framework synthesis & Using the best fit framework, highlight findings from the literature \\
\hline
\end{tabular}

The study aims to contribute to the ongoing debate about the impact of industry on the future of our planet and society. We structured the paper as follows: Stage 1 presents a descriptive outline of the literature on sustainable business models and its dimensions. In Stage 2, the scope of the review, research design and synthesis approach are explained. Stage 3 presents the synthesis and findings of sustainable business models in the literature. Finally, we draw conclusions and highlight implications and avenues for future research.

\section{PREVIOUS SYSTEMATIC LITERATURE REVIEWS}

At the time of writing, a range of reviews related to our research area has been published. However, they review sustainable business models in manufacturing from a different focus. The reviews and their focus are summarized in Table 2.

Table 2. Previous systematic literature reviews and focus.

\begin{tabular}{ll}
\hline Publication & Focus \\
\hline Pacheco, Caten, Jung, Sassanelli, and Terzi (2019) & $\begin{array}{l}\text { Using empirical studies to understand how small- and medium-sized } \\
\text { enterprises in manufacturing overcome barriers toward the sustainable PSS } \\
\text { archetype }\end{array}$ \\
Kravchenko, Pigosso, and McAloone (2019) & $\begin{array}{l}\text { Consolidation of leading sustainability-related performance indicators into } \\
\text { a database with a relevance for manufacturing companies in the circular } \\
\text { economy archetype }\end{array}$ \\
Cioff, Travaglioni, Piscitelli, Petrillo, and Parmentola (2020) & $\begin{array}{l}\text { A documentary analysis of conceptual, methodological, and application } \\
\text { papers to show how smart manufacturing systems contribute to a sustainable } \\
\text { industry in the circular economy archetype }\end{array}$ \\
Caldera, Desha, and Dawes (2017) & $\begin{array}{l}\text { Using conceptual and empirical studies to understand how lean and green } \\
\text { initiatives could lead to sustainable business practice in manufacturing } \\
\text { companies }\end{array}$ \\
\hline
\end{tabular}

These reviews are relatively new, and while they deal with the building blocks of sustainable business models within specific archetypes (for example, circular economy, PSS, lean manufacturing), the research gap therein is that they do not provide an overview of the strategies manufacturing companies employ and barriers that they face across the sustainability spectrum. Using a similar approach as some of the previous papers, we aim to address that research gap.

\section{STAGE 1: DEVELOPING AN INITIAL ARCHITECTURE FOR REVIEWING SUSTAINABLE BUSINESS MODELS}

Drawing on the archetypes proposed by Bocken, Short, Rana and Evans (2014), we outline the initial framework for sustainable business models. This framework forms the basis for identifying, analyzing, and synthesizing sustainable business models and practices from the selected studies.

\section{Sustainable business models}

Business activities can be traced to the practice of trade by barter, but the business model concept became a mainstream discourse in practice and research quite recently. According to Zott, Amit, and Massa (2011), business models have been referred to as a statement, a description, a representation, an architecture, a conceptual tool or model, a structural template, a method, a framework, a pattern and as a set. It tells a story of how a firm does business by creating, capturing, and delivering value at an appropriate cost to different stakeholders relying on financial, human, 
and natural capital (Casadesus-Masanell \& Ricart, 2010; Doganova \& Eyquem-Renault, 2009; Magretta, 2002; Massa, Tucci, \& Afuah, 2017). Traditional business models are tied to profit generation and exploitation of competitive advantage (Casadesus-Masanell \& Ricart, 2010), which are built upon essential but limited non-financial resources (Clinton \& Whisnant, 2019). "How do we make money in this business?" (Magretta, 2002, p. 87) - seems to be a continuous and pressing issue for businesses. An issue which is usually solved at the detriment of the environment and society. These issues highlighted the importance of firms to contribute toward sustainable development.

Climate change, resource depletion, poverty, and overconsumption have challenged individuals, industry, and government to engage in an effort toward sustainable development. Sustainable development, encompassing present and future generations, is relevant to all levels of human activity. From an organizational point of view, this entails a long-term approach in managing responsibilities for environmental stewardship, social well-being, and economic prosperity while staying accountable to all stakeholders (Pojasek, 2012). In this era of globalization, firms must be more competitive and with the pressure of society and government on businesses to contribute toward sustainable development goals, conventional business models are hardly the way forward. Sustainable business models, alternatively, aim to create value for the economy, society, and environment. In practice, this issue might not be nearly as simple as it seems, and it might not always be clear what traits differentiate a sustainable organization from the competition. In his 1997 book Cannibals with forks, Elkington (1997) metaphorically infers that real progress would occur when cannibals (businesses aiming to devour their competitors) learn how to use the fork (the concept of sustainable business) and also change their diets to wholesome ones that benefit everyone involved (the concept of responsibility). Businesses can seek profits, but in the long term, the problems they create for society and the environment should be properly handled or eliminated. All stakeholders associated with the industrial value chain must apply new ways of thought and actions to tackle the sustainability challenge.

\section{Sustainable business model archetypes}

To account for the triple bottom line in the manufacturing sector, we investigated the literature to understand different classifications of sustainable business models. We used the archetypes originally developed by Bocken et al. (2014), who used them to "describe groupings of mechanisms and solutions that may contribute to building up the business model for sustainability" (Bocken et al., 2014, p. 45). These archetypes were updated in 2016 as seen in Figure 1 to include a broader scope (Bocken, Weissbrod, \& Tennant, 2016) (see Appendix for complete framework). They broke down the broad nature of approaches in sustainable business modeling into a substantial framework.
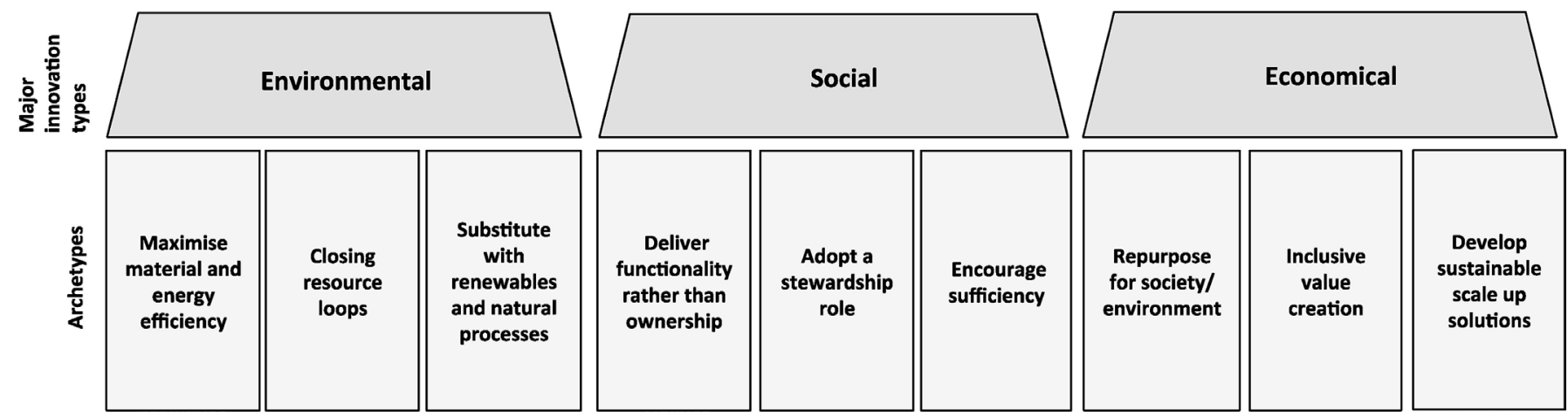

Figure 1. Sustainable business model dimensions and archetypes.

Source: Ritala, P., Huotari, P., Bocken, N., Albareda, L., \& Puumalainen, K. (2018). Sustainable business model adoption among S\&P 500 firms: A longitudinal content analysis study. Journal of Cleaner Production, 170, 216-226. https://doi.org/10.1016/j.jclepro.2017.09.159

\section{Environmental}

Most of the discourse around sustainability places heavy focus on the environmental dimension of sustainability. The environment is one of the most exploited resources during the course of human development and traditionally, industries considered the environmental sustainability agenda as one with extra costs that dampens financial profitability, competitive growth, and market advantage (Kemp \& Andersen, 2004; Porter \& Van Der Linde, 1995). Industries undertook reactive strategies because they were obliged to do so by regulation and policy. However, proactive 
measures have risen slowly and steadily over the years. During the last decade, these measures have been recognized as important drivers of competitive advantage and economic development (Andersen, 2015; Maçaneiro \& Cunha, 2014). Regarding value creation, this dimension focuses on maximizing material and energy efficiency, closing resource loops, and substituting fossil fuels with renewables and natural processes (Bocken, Weissbrod, et al., 2016).

Social

In the 1950s, social audits attempted to make businesses more accountable to society by communicating economic and non-economic impacts to the community they serve (Hazarika, 2015). Over time, different approaches to doing good for society have emerged. These approaches are seen as responsible but they were criticized for not resolving an underlying core issue or contributing to sustainable development - especially in developing societies (McLennan \& Banks, 2019). Sustainability advocates have instead called for industry to focus on creating and delivering social value if it wishes to contribute to sustainable development. A lot of the input on sustainable social value deals with poverty alleviation, community development, diversity and equality, amongst others (Freudenreich, Lüdeke-Freund, \& Schaltegger, 2020). These values center around delivering functionality rather than ownership, adopting a stewardship role and encouraging sufficiency (Bocken, Weissbrod, et al., 2016). They are hard to measure and as a result, a lot of the work regarding the measurement of the social dimension of sustainability is still ongoing (Geibler, Liedtke, Wallbaum, \& Schaller, 2006; Yunus, Moingeon, \& Lehmann-Ortega, 2010).

\section{Economic}

Firms aim to be economically sustainable. The traditional view of economic sustainability is profitable growth, return on investments, and long-term viability and stability of the business (Freudenreich et al., 2020). This has improved the wellbeing of humans through industrialization and production efficiency. Ultimately, the pursuit of profit and wealth maximization for shareholders has led to the overexploitation of natural and human capital. This approach has also been criticized for having a skewed view of judging societal success (Anand \& Sen, 2000). With the turn of the decade, firms have understood that it is necessary to provide economic value to a wider sphere of entities besides shareholders. In this regard, sustainable economic values center around repurposing for society/environment, engaging in inclusive value creation, and developing sustainable scale up solutions (Bocken, Weissbrod, et al., 2016).

\section{STAGE 2: SYSTEMATIC LITERATURE REVIEW OF SUSTAINABLE BUSINESS MODELS}

\author{
We conduct a systematic literature review (SLR)
} of the literature on sustainable business models published in the following databases: Scopus, Web of Science, and ProQuest. The literature with a focus on manufacturing began to increase around 2009 with a higher frequency in the last five years.

To conduct our review, we used the five-step approach by Denyer and Tranfield (2009), which after formulating a question, "locates existing studies, selects and evaluates contributions, analyzes and synthesizes data, and reports the evidence in a way that allows reasonably clear conclusions to be reached about what is and is not known" (Denyer \& Tranfield, 2009, p. 671). We use an algorithm to search for empirical literature, and to evaluate and categorize them. This makes the process of conducting SLRs replicable, scientific, and transparent. An advantage of SLRs over other review methods is that it aims to provide the state of the art in a wide range of disciplines, minimizing bias, identifying research gaps, and, at the same time, informing and unifying practitioner and researcher communities (Crowther \& Cook, 2007; Denyer \& Tranfield, 2009; Thorpe, Holt, Macpherson, \& Pittaway, 2005; Tranfield, Denyer, \& Smart, 2003)

\section{Question formulation}

Research done on sustainable business models has been steadily increasing. This review is based on sustainable business model activities in empirical studies. We investigate sustainable business models using the following research question: What is the trend in empirical literature on how different industries in the manufacturing sector implement sustainable business models?

To answer this research question, we developed the following questions to guide the analysis: (a) What archetypes do researchers report when empirically investigating how various industries in the manufacturing sector lean toward implementing sustainable value?; and (b) What challenges are observed in the literature when industries move toward creating and delivering sustainable value in manufacturing?

Due to the nature of these questions, we chose to use a qualitative analysis of the results reported in the empirical studies. The results in the empirical studies are primarily qualitative by nature, therefore requiring a corresponding data analysis and synthesis approach. 


\section{Locating studies}

To search adequately and ensure traceability, we used relevant keywords associated with the scope of the article and our research questions. We choose these keywords to capture relevant papers dealing with business models while accounting for sustainability. We enabled wildcards to avoid issues regarding variants and plural forms, and search results were limited to papers published in English. The string (as shown in Table 3) was adapted for each database as the search mechanisms behind them are slightly different. The search was last conducted in April 2020.

Sustainability is a trending concept and, hence, the discourse on sustainable business models can be found in different types of documents. For this review, we included peer-reviewed articles and reviews in scholarly journals, conference papers, and proceedings.

Table 3. Selected databases and search strings.

\begin{tabular}{|c|c|}
\hline Database & Search string \\
\hline Web of Science & $\begin{array}{l}\text { (TI=(sustainab*) AND TS=(“business model*” AND “manufactur*”)) AND LANGUAGE:(English) AND DOCUMENT } \\
\text { TYPES:(Article OR Proceedings Paper OR Review) }\end{array}$ \\
\hline ProQuest & $\begin{array}{l}\text { ti(sustainab*) AND ab("business model*" AND "manufactur*”) AND stype.exact("Working Papers" OR "Scholarly Journals") } \\
\text { AND la.exact("English") AND stype.exact("Conference Papers \& Proceedings" OR "Working Papers" OR "Scholarly Journals") } \\
\text { AND at.exact("Literature Review" OR "Review" OR "Conference Proceeding" OR "Conference Paper" OR "Conference" OR } \\
\text { "Article") }\end{array}$ \\
\hline Scopus & $\begin{array}{l}\text { (TITLE( sustainab*) AND TITLE-ABS-KEY(“business model*” AND “manufactur*”)) AND DOCTYPE(ar) OR } \\
\text { DOCTYPE(re) OR DOCTYPE(cp) AND (LIMIT-TO(LANGUAGE, “English”)) }\end{array}$ \\
\hline
\end{tabular}

\section{STUDY SELECTION/EVALUATION}

In total, we downloaded 561 results. We uploaded these results into Rayyan (available at https://rayyan.qcri.org/ retrieved in April 30, 2020). The samples, after cleaning, were screened for relevance by reading the titles, abstracts, and keywords. Inclusion criteria are articles based on empirical research, articles using primary data. The initial sample highlights some interesting information. As depicted in Figure 2, the number of publications investigating sustainable business models in manufacturing has increased remarkably in the past five years. Only two documents were published in this area in 2002 compared to 40 in
2018. So far as of April 2020, 14 documents had been published before the middle of the year, thus, implying that major developments have been going on in research and practitioners within the manufacturing sector are utilizing sustainable business models.

From this initial sample, we excluded articles with a focus on simulation and conceptual papers. We also excluded articles that used secondary data and articles that were ambiguous about the type of company investigated. After the selection and screening process, we considered 21 documents relevant for this study. Figure 3 shows the search and filter strategy and a full list and general overview of these articles are shown in Appendix B.

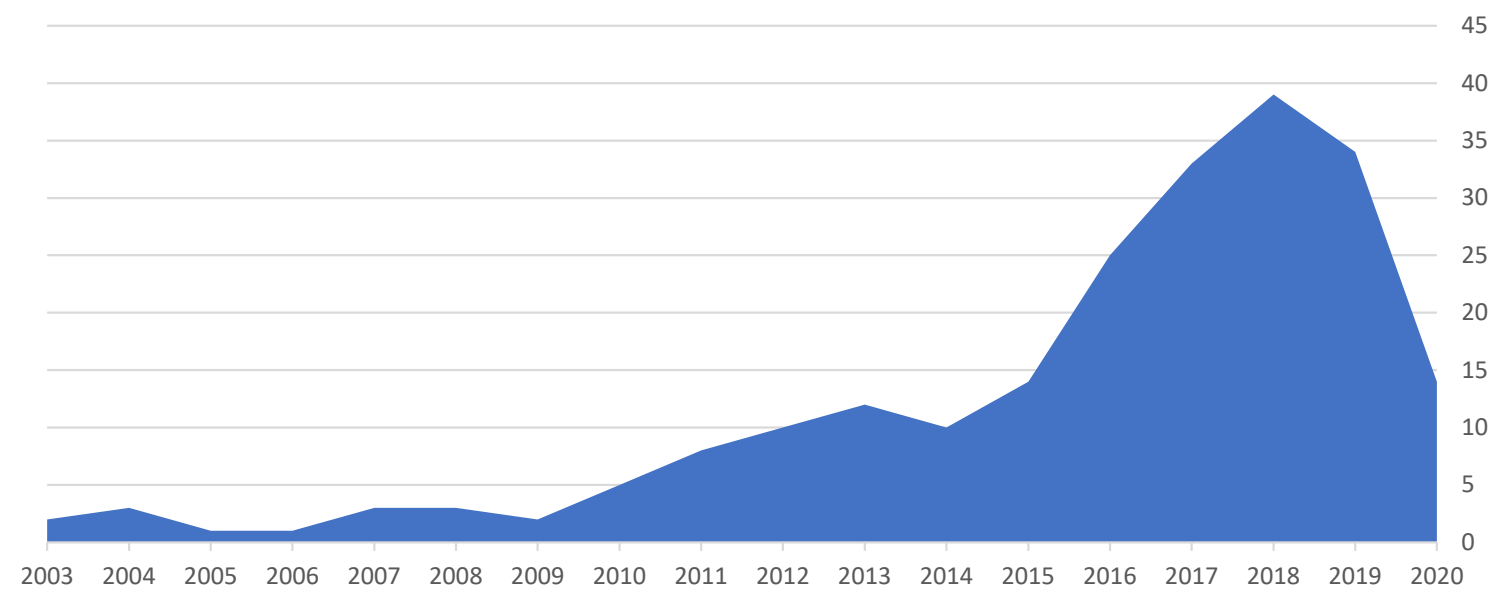

Figure 2. Publication trend using the search criteria. 


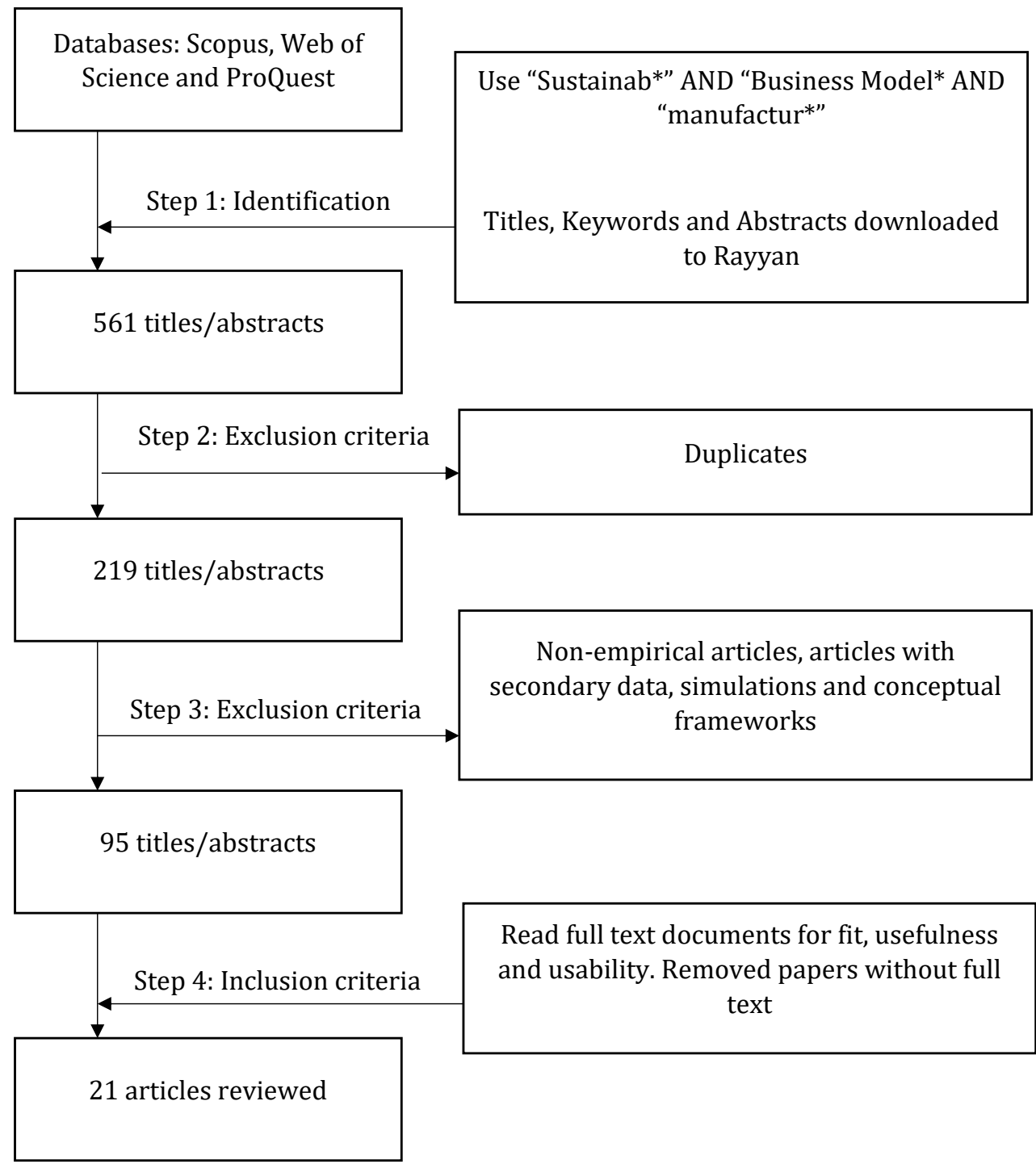

Figure 3. Search and filter strategy.

\section{Analysis/synthesis}

We used the UN International Standard Industrial Classification system to place the papers in different industries. We extracted our data using the 'initial architecture' and conducted further synthesis. We fit them into the sustainable business archetypes developed by Bocken, Weissbrod and Tennant (2016) (see Appendix for full archetypes) in line with the best fit framework by Carroll, Booth, and Cooper (2011). Subsequently, we further investigated the evidence to understand emerging challenges in the literature. This way of working made it possible to get a cumulative picture of the activities described in the different empirical papers. The formulation of these activities is presented in Stage 3.

\section{STAGE 3: FRAMEWORK SYNTHESIS}

The best fit framework approach produces a rapid, transparent, and pragmatic process (Carroll, Booth, Leaviss, \& Rick, 2013), appropriate when addressing questions related to features of activities. It highlights strategies, contributions, and challenges faced by businesses when implementing sustainable business models.

We used the dimensions of sustainability as the initial 'architecture' for reviewing the literature. The synthesis groups and expands the findings to show the key activities reported in the following dimensions, respectively: environmental, social, and economic. 


\section{Environmental value creation}

Table 4. Closing resource loops.

\begin{tabular}{|c|c|c|c|c|}
\hline Sub-category & Authors & Division & Case & Challenges \\
\hline $\begin{array}{l}\text { Reduce, reuse, re- } \\
\text { manufacture }\end{array}$ & Jiao \& Evans (2017) & $\begin{array}{l}\text { Electrical equipment; motor } \\
\text { vehicles }\end{array}$ & $\begin{array}{l}\text { Repurpose EOL EV } \\
\text { batteries as energy storage }\end{array}$ & $\begin{array}{l}\text { Limited market share; early } \\
\text { stage business case }\end{array}$ \\
\hline \multirow{2}{*}{$\begin{array}{l}\text { Circular economy, closed } \\
\text { loop }\end{array}$} & $\begin{array}{l}\text { Wanniarachchi, } \\
\text { Dissanayake, \& Downs } \\
(2020)\end{array}$ & Textiles & $\begin{array}{l}\text { Using waste from textile } \\
\text { manufacturing to create } \\
\text { various by-products }\end{array}$ & $\begin{array}{l}\text { Structural barriers hindering } \\
\text { innovation in the local } \\
\text { context }\end{array}$ \\
\hline & $\begin{array}{l}\text { García-Muiña, Medina- } \\
\text { Salgado, Ferrari, \& Cucchi } \\
(2020) \text {; }\end{array}$ & $\begin{array}{l}\text { Non-metallic mineral } \\
\text { products }\end{array}$ & $\begin{array}{l}\text { Using industry } 4.0 \text { in } \\
\text { circular economy in ceramic } \\
\text { tile manufacturing }\end{array}$ & $\begin{array}{l}\text { Risk of producing non- } \\
\text { compliant products }\end{array}$ \\
\hline Cradle to cradle & $\begin{array}{l}\text { Jacques, Agogino, \& } \\
\text { Guimaraes (2010) }\end{array}$ & Leather and related products & $\begin{array}{l}\text { Incorporation of recycled } \\
\text { and environmentally } \\
\text { preferred material }\end{array}$ & $\begin{array}{l}\text { Product return strategies for } \\
\text { recycling had limited success }\end{array}$ \\
\hline
\end{tabular}

By closing resource loops (Table 4), manufacturing companies identify and create value from the loop between post-use and production (Bocken, Pauw, Bakker, \& Van Der Grinten, 2016). Jiao and Evans (2017) studied the secondary use of electric vehicle (EV) batteries at their end of life (EOL). They identified unsustainable issues plaguing the EV industry such as inconvenience, high prices, and pollution and stated that although repurposing EOL EV batteries will not immediately solve these issues, it is a promising approach to reducing EV cost hurdle. If stakeholders collaborate, this will improve the sustainable performance of the technology. Their findings indicate second life batteries have a wide potential for application, but on one hand, EVs need to be adopted by the mass market to reduce their prices. On the other hand, however, a reduction in price of EVs is needed to cater to the mass market and this challenge feeds into the business model of EOL EV battery reuse.

García-Muiña, Medina-Salgado, Ferrari and Cucchi (2020) and Wanniarachchi, Dissanayake and Downs (2020) studied circular economy in local contexts of manufacturing. Wanniarachchi et al. (2020) investigated the sustainable and ethical manufacturing practices of Sri Lankan textile manufacturer. The companies focused on employing fair trade practices and using $100 \%$ of textile waste to create various by-products for export. This approach enabled product and market diversification. In this context, structural barriers and lack of access to markets and innovation hinder growth. On the other hand, García-Muiña et al. (2020) evaluated the transition to a sustainable model for ceramic tile production in Italy. They noted that this transition was facilitated by industry 4.0 tools, enabling increased efficiency and monitoring of manufacturing processes, hence, the environmental benefits could be quantified. If the technological performance of the product is not considered when implementing sustainable business models, there is a risk of creating a subpar product.
Jacques, Agogino and Guimaraes (2010) characterized the sustainable product development initiatives in footwear industry to show how the product development process could enable sustainable products. They compared case studies in America and Brazil from the cradle-to-cradle perspective. Their findings indicated that initiatives taken by footwear companies involve materials reutilization, resource consumption, and social responsibility. Although companies follow different strategies to tackle their sustainability problems, the industry still has a long way to go with regard to sustainability. A common challenge in achieving closed loop production is that consumers seldom return apparel items after use for recycling. In addition, take-back initiatives in the footwear industry were met with limited success. They suggested offering incentives to encourage consumer participation.

When companies do more with fewer resources, less waste, emissions, and pollution are generated (Bocken et al., 2014). Kiel et al. (2017) studied a range of companies in machinery, electric, and motor vehicle manufacturing to understand the prevalent benefits and challenges brought about by the adoption of industrial internet of things (IIoT). They found that creating sustainable value through IIoT was perceived to enable lean manufacturing while enhancing competitiveness and resource efficiency, improving financial standing, and enabling new business models. They observed a range of challenges faced by companies implementing IIoT with the most frequent being technical challenges. González-Varona et al. (2020) also made a case for additive lean manufacturing in making electronic spare parts. They argued that by combining cloud connections and internet of things (IoT), spare parts for damaged electronic components in high-tech furniture and medical devices could be $3 \mathrm{D}$ printed at a localized point before distribution. They identified that although challenges might occur in certifying the quality of the manufactured 
part, such a business model would benefit SMEs, customers, and the environment.

Dematerializing products packaging can also improve resource efficiency. In Bogers et al. (2020), they illustrate how sustainability challenges in packaging can be addressed through open innovation in the beverage industry. The cooperation between beverage and package manufacturers resulted in the development of a fully biodegradable beverage bottle made from paper. To fully realize the potential of the project, the beverage company was open to collaboration with others - including competitors. In this context, the challenge was branded waste, where discarded products have the company's logo. This strategy might also compete with well-functioning methods of glass collection and recycling.

Hogevold and Svensson (2012) examined a European furniture manufacturer. The case company had gone through a complete overhaul to reduce its carbon footprint in all aspects of its value and supply chain. They hint that applying this strategy across the whole chain might be challenging but requires a genuine long-term commitment.

Table 5. Maximize material and energy efficiency.

\begin{tabular}{|c|c|c|c|c|}
\hline Sub-category & Authors & Division & Case & Challenges \\
\hline \multirow[t]{2}{*}{ Lean manufacturing } & $\begin{array}{l}\text { Kiel, Muller, Arnold, and } \\
\text { Voigt (2017) }\end{array}$ & $\begin{array}{l}\text { Motor vehicles; machinery } \\
\text { and equipment }\end{array}$ & $\begin{array}{l}\text { Creating sustainable value } \\
\text { using industrial internet of } \\
\text { things }\end{array}$ & $\begin{array}{l}\text { Technical integration of } \\
\text { IIoT; increased competition; } \\
\text { lack of flexibility to } \\
\text { cooperation }\end{array}$ \\
\hline & $\begin{array}{l}\text { González-Varona, Poza, } \\
\text { Acebes, Villafáñez, Pajares, } \\
\text { and López-Paredes (2020) }\end{array}$ & $\begin{array}{l}\text { Computer, electronic, } \\
\text { and optical products; } \\
\text { manufacture of furniture }\end{array}$ & $\begin{array}{l}\text { 3D printing to provide } \\
\text { localized spare parts } \\
\text { solutions for SMEs }\end{array}$ & $\begin{array}{l}\text { Quality certification of spare } \\
\text { parts }\end{array}$ \\
\hline $\begin{array}{l}\text { Dematerialization of } \\
\text { products/packaging }\end{array}$ & $\begin{array}{l}\text { Bogers, Chesbrough, and } \\
\text { Strand (2020) }\end{array}$ & Beverages & $\begin{array}{l}\text { Biodegradable beverage } \\
\text { bottle }\end{array}$ & $\begin{array}{l}\text { Unexpected negative } \\
\text { outcomes such as branded } \\
\text { waste } \\
\text { Competition with current } \\
\text { systems }\end{array}$ \\
\hline $\begin{array}{l}\text { Low carbon manufacturing/ } \\
\text { solutions }\end{array}$ & $\begin{array}{l}\text { Hogevold and Svensson } \\
(2012)\end{array}$ & Manufacture of furniture & $\begin{array}{l}\text { Minimizing impact of the } \\
\text { entire chain on the natural } \\
\text { environment }\end{array}$ & $\begin{array}{l}\text { Possible, challenging to } \\
\text { apply it to the whole supply } \\
\text { chain }\end{array}$ \\
\hline
\end{tabular}

Table 6. Substitute with renewables and natural processes.

\begin{tabular}{|c|c|c|c|c|}
\hline Sub-category & Authors & Division & Case & Challenges \\
\hline \multirow{2}{*}{$\begin{array}{l}\text { Move from non-renewable } \\
\text { to renewable energy sources }\end{array}$} & Lyytinen (2017) & Electrical equipment & Biomass technologies & $\begin{array}{l}\text { High maintenance } \\
\text { requirements; high financial } \\
\text { requirements }\end{array}$ \\
\hline & Lin et al. (2018) & Motor vehicles & $\begin{array}{l}\text { Manufacture of new energy } \\
\text { vehicles }\end{array}$ & $\begin{array}{l}\text { High energy consumption } \\
\text { during the fixed use stage of } \\
\text { the product }\end{array}$ \\
\hline Zero emissions initiative & $\begin{array}{l}\text { Rajala, Westerlund, \& } \\
\text { Lampikoski (2016) }\end{array}$ & Textiles & $\begin{array}{l}\text { Mission Zero strategy } \\
\text { to eliminate all negative } \\
\text { impacts }\end{array}$ & $\begin{array}{l}\text { Managers may not manage } \\
\text { transformation if they } \\
\text { lack the understanding of } \\
\text { sustainable business models }\end{array}$ \\
\hline
\end{tabular}

While improving resource efficiency and creating value from waste focus on reducing environmental impacts, Bocken et al. (2014) argue that these do not consider the potential benefits from renewable resources and natural processes where environmentally sustainable value is created in a more significant manner. Lyytinen (2017) explored sustainable business models of small-scale bioenergy solutions in high- and low-income contexts. In the high- income context, wood chips were utilized in a fully automated solution targeted to wealthy customers while in the low-income context, organic waste were utilized in a lowcost solution targeted to the poor. The findings indicated that promoting sustainability in different parts of the world requires radically different design and manufacturing approaches. However, the solutions required high financial requirements with the low-income context requiring high 
level of maintenance. Lin et al. (2018) analyzed sustainable business models in the new energy vehicles through a single case study of a car manufacturer in China. In this case, the case company uses this approach to target a combination of mass market and the public sector. They noted that a large impact of this application of renewable energy was large energy consumption during the use stage of the vehicle. These challenges from both studies correlate with Bocken et al. (2014), who stated that moving from non-renewables to renewables is not yet economically viable or cannot be made efficiently at volume. Nonetheless, progress is being made.

Rajala et al. (2016) studied the business model of a textile manufacturer. The authors wanted to improve the understanding on how a manufacturer can implement sustainability-driven change in its business model. The case company changed some of old practices to leverage the green vision. It started with a cradle-to-cradle concept before reevaluating its business model to eliminate any negative impact the company and its partners might have on the environment. The challenge in this context was that because this involves overhauling traditions, managers might be illequipped to handle such transformation if they have little understanding of how sustainable business models work.

\section{Sustainable social value creation}

Carayannis et al. (2015) and Hankammer et al. (2018) discuss encouraging sufficiency. Products and services under this archetype aim to reduce production by the manufacturers and consumption by customers/end-users (Bocken et al., 2014). The articles deal with product longevity and contribute to the discourse about the effects of overconsumption and overproduction of electrical and electronic goods. In the case presented by Hankammer et al. (2018), mass customization of smartphones was presented to improve product longevity in the smartphone market. Their findings indicated the social value of such a solution being high especially when specific features required by the user could be integrated. They claim that case product failed due to reasons including economic, organizational, and technical difficulties. In the case presented by Carayannis et al. (2015), the company was a success due to an overhaul of the business model at an organizational level. The case company, being the first to introduce LED lighting into Thailand, found itself able to compete at the level of quality by switching to producing customized lighting solutions that lasted longer than the competition.

Table 7. Archetype: Encourage sufficiency.

\begin{tabular}{|c|c|c|c|c|}
\hline Sub-category & Authors & Division & Case & Challenges \\
\hline \multirow[t]{2}{*}{ Product longevity } & $\begin{array}{l}\text { Carayannis, Sindakis, and } \\
\text { Walter (2015) }\end{array}$ & Electrical equipment & $\begin{array}{l}\text { Customized long-lasting } \\
\text { LED solutions }\end{array}$ & $\begin{array}{l}\text { Lack of organizational } \\
\text { flexibility might hinder } \\
\text { adoption }\end{array}$ \\
\hline & $\begin{array}{l}\text { Hankammer, Jiang, Kleer, } \\
\text { and Schymanietz (2018) }\end{array}$ & $\begin{array}{l}\text { Computer, electronic, and } \\
\text { optical products }\end{array}$ & $\begin{array}{l}\text { Modular and customizable } \\
\text { smartphones }\end{array}$ & $\begin{array}{l}\text { Technical difficulties; } \\
\text { implementation issues }\end{array}$ \\
\hline
\end{tabular}

Table 8. Archetype: Deliver functionality rather than ownership.

\begin{tabular}{|c|c|c|c|c|}
\hline Sub-category & Authors & Division & Case & Challenges \\
\hline \multirow{5}{*}{$\begin{array}{l}\text { Result oriented PSS- } \\
\text { pay per use }\end{array}$} & $\begin{array}{l}\text { Yang, Evans, Vladimirova, } \\
\text { and Rana (2017) }\end{array}$ & $\begin{array}{l}\text { Electrical equipment; } \\
\text { motor vehicles; machinery } \\
\text { and equipment }\end{array}$ & $\begin{array}{l}\text { Energy as a service; mobility } \\
\text { as a service; gas as a service; } \\
\text { integrated video solutions as } \\
\text { a service }\end{array}$ & $\begin{array}{l}\text { Lack of freedom to use excess waste; } \\
\text { risk of crossing into other industrial } \\
\text { sectors; negotiation processes }\end{array}$ \\
\hline & $\begin{array}{l}\text { Fargnoli, Costantino, Di } \\
\text { Gravio, and Tronci (2018) }\end{array}$ & $\begin{array}{l}\text { Computer, electronic, and } \\
\text { optical products }\end{array}$ & $\begin{array}{l}\text { Lifecycle management of } \\
\text { medical devices }\end{array}$ & $\begin{array}{l}\text { Complexity of managing issues } \\
\text { associated with PSS increases in } \\
\text { regulated environments }\end{array}$ \\
\hline & $\begin{array}{l}\text { Homrich, Theodoro, and } \\
\text { Carvalho (2017) }\end{array}$ & Food products & $\begin{array}{l}\text { Olive farmers with extraction } \\
\text { equipment selling extraction } \\
\text { services during their idle } \\
\text { periods }\end{array}$ & $\begin{array}{l}\text { Needs considerable investment and } \\
\text { operations costs }\end{array}$ \\
\hline & Kiel et al. (2017) & Electrical equipment & $\begin{array}{l}\text { Using industrial internet of } \\
\text { things to create sustainable } \\
\text { value }\end{array}$ & $\begin{array}{l}\text { High competition; technical } \\
\text { difficulties }\end{array}$ \\
\hline & $\begin{array}{l}\text { Reim, Lenka, Frishammar, } \\
\text { and Parida (2017) }\end{array}$ & $\begin{array}{l}\text { Machinery and } \\
\text { equipment }\end{array}$ & $\begin{array}{l}\text { Availability based contract for } \\
\text { construction equipment }\end{array}$ & $\begin{array}{l}\text { Increased risks over long periods; } \\
\text { risk of adverse market selection }\end{array}$ \\
\hline $\begin{array}{l}\text { Use oriented PSS- } \\
\text { rental, lease, shared }\end{array}$ & Lindstrom (2016) & $\begin{array}{l}\text { Electrical equipment; } \\
\text { motor vehicles }\end{array}$ & $\mathrm{N} / \mathrm{A}$ & $\begin{array}{l}\text { Unpredictable changes with long } \\
\text { durations }\end{array}$ \\
\hline Product-oriented PSS & Marcus (2018) & Wearing apparel & $\begin{array}{l}\text { HRM impacts in providing } \\
\text { services to customers }\end{array}$ & $\begin{array}{l}\text { Large investment costs; extra } \\
\text { effort required to reduce employee } \\
\text { turnover }\end{array}$ \\
\hline
\end{tabular}


Bocken et al. (2014) postulate that value can also be provided by providing services, satisfying users' needs without them having to own physical products. The articles by Fargnoli et al. (2018), Homrich et al. (2017), Kiel et al. (2017), and Yang et al. (2017) study how functionality can be delivered via a result-oriented product service system. Their findings indicate that for products to be servitized, businesses should prepare for a higher level of competition. Nonetheless, it is possible for small businesses to receive value from their bigger competitors in this context. In the study by Homrich et al. (2017), resultoriented PSS enabled new business opportunities previously limited to producers with large investment possibilities. In that case, olive farmers who had equipment oversized for their production sold the olive oil extraction service to smaller farmers during reduced production period. They hint that by employing PSS, satisfaction is not restricted to consumer use, but expands to community participation or knowledge/information sharing. By studying changes adopted in a product's lifecycle, Fargnoli et al. (2018) observed customer satisfaction and reduced negative effects on the environment. Their study concerns a regulated biomedical device environment, and due to this, it is noted that managing issues associated with PSS becomes more complex. Yang et al. (2017) argued that in manufacturing, customer needs are usually complex, hence, PSS business models provide companies with more opportunities to communicate with customers and understand their needs. They provide insight on how companies, when transitioning to providing services, can use the perspective of value uncaptured - "the set of benefits that could be captured but have not yet been captured" (Yang, Evans, Vladimirova, \& Rana, 2017, p. 1801) to create sustainable business models. Kiel et al. (2017) posit that by introducing internet of things into the value chain, manufacturers can collect large amounts of data to provide sustainable value. Businesses should be able to foresee technical complexities involved with this.

Lindstrom (2016) and Reim et al. (2017) studied how equipment can be servitized with a use-oriented PSS. In Lindstrom (2016), a business might be innovative in offering its products and services via functional products. These have the potential to provide sustainability-oriented value for customers and the business. Reim et al. (2017) found that in addition to taking over responsibilities from the customer, operational activities can also be handled by the supplier. Both articles note that due to the long duration of contracts, unpredicted risks come into play but there might be managed effectively and those outside the control of the supplier can be covered through risk-sharing contracts between both parties.

Marcus (2018) studied the impact of HRM on fashion firms employing PSS in their business models. The study showed that compared to others, firms that employed PSS focused on a higher spectrum of HRM components such as human capital, employee commitment, and people management. The findings also indicated that in firms that implemented PSS, the employees demonstrate a higher level of affective commitment to co-create value, as well as build and maintain trustful relationships with collaborators and customers.

Table 9. Archetype: Adopt a stewardship role.

\begin{tabular}{|c|c|c|c|c|}
\hline Sub-category & Authors & Division & Case & Challenges \\
\hline $\begin{array}{l}\text { Radical transparency about } \\
\text { environmental/societal } \\
\text { impacts }\end{array}$ & $\begin{array}{l}\text { Pinna, Demartini, Tonelli, } \\
\text { and Terzi (2018) }\end{array}$ & Beverages & $\begin{array}{l}\text { Selecting KPIs for } \\
\text { sustainable manufacturing } \\
\text { of soft drinks }\end{array}$ & $\begin{array}{l}\text { The process of selecting KPIs } \\
\text { is not an intuitive one, and } \\
\text { the KPIs are not necessarily } \\
\text { related to the function of the } \\
\text { product being manufactured }\end{array}$ \\
\hline
\end{tabular}

Bocken et al. (2014) selected adopting a stewardship role because it "maximizes the positive societal and environmental impacts of the firm by ensuring long-term health and well-being of all stakeholders." (Bocken et al., 2014, p. 51) In Pinna et al. (2018), sustainability KPIs were collected to show how soft drink manufacturers can maximize positive impacts along four sections: materials and packaging, water and energy, emissions, and other general aspects. Here, critical issues soft drink companies focus on are mainly connected to material reduction and recycling, or resources conservation. Challenges occur in applying sustainability KPIs in practice, as it is not an intuitive process along the whole supply chain.

\section{Economic value creation}

Bocken, Weissbrod, et al. (2016) added inclusive value creation to the archetypes to encompass value creation for a broader base. These are business models based around resource sharing as well as knowledge, ownership, and wealth creation. Li et al. (2020) investigated how co-creation can deliver sustainable value through a digital twin platform 
network. Such a platform can provide a comprehensive overview of products, manufacturing processes, supply chain, customer experience, and profitability. In the case study, this enabled the manufacturer to provide smart solutions based on specific customer needs. The challenge here involves a difficulty in adjusting from an enterprisefocused strategy to a user-focused strategy.

Table 10. Archetype: Inclusive value creation.

\begin{tabular}{|c|c|c|c|c|}
\hline Sub-category & Authors & Division & Case & Challenges \\
\hline Value co-creation & $\begin{array}{l}\text { Li, Cao, Liu, and Luo } \\
(2020)\end{array}$ & Electrical equipment & $\begin{array}{l}\text { Custom solutions using } \\
\text { digital twin platform }\end{array}$ & $\begin{array}{l}\text { Adjusting to a user-centered } \\
\text { focus; degree of openness to } \\
\text { collaboration }\end{array}$ \\
\hline
\end{tabular}

\section{CONCLUSION AND FUTURE DIRECTIONS}

Transitioning to sustainable business models and processes in the manufacturing sector is highly crucial as the industry has been accused of exploiting the world's resources on its journey to growth. Through a systematic literature review, this study shows how the manufacturing sector integrates sustainability into its business models and processes. Such contribution is of relevance for researchers, consultants, and practitioners who work in this sector. A key contribution is to provide a better understanding of the opportunities and challenges faced by companies that are implementing sustainable business models currently. The study also contributes to investigating how the framework proposed by Bocken, Weissbrod, et al. (2016) fits the empirical literature. Using a novel systematic review process, the study synthesized 21 empirical articles. They were analyzed with the authors' understanding of the business model and sustainability concepts. As noted in the introduction, there have been several articles reviewing the literature on sustainable business models in manufacturing. Using the best-fit approach, this article filled a gap in previous research by highlighting the reported strategies employed by manufacturing companies and the potential barriers they face in pursuing the different SBM archetypes.

The cases presented in the literature review highlight evidence that there is a diverse set of business model strategies manufacturing companies employ to provide sustainable value. Eleven articles focused on providing environmental value and ten articles focused on providing societal value. This shows that there are some steps taken to provide value and slow down on exploitation of resources it depends on. On the other hand, it also highlights that there are still unexplored strategies that could be employed in the manufacturing industry.

Although the literature is increasing, only a small number of studies are concerned with providing economic value in this context. In retrospect, this indicates that economic value is most likely still considered in terms of financial outcomes and profitable growth rather than value creation in terms of repurposing for the society/environment, as well as developing scale-up solutions and inclusive value creation. The cases show that no matter the strategy involved in providing value, transitioning to a sustainable business model implies an overhaul of the traditional business model and would involve a continuous long-term perspective on evolving business processes.

Elkington (1998) advised businesses to ensure that sustainability is on their growth agenda. As observed in multiple articles, the current traditions might be hard to change, but firms should be flexible and willing to develop new expertise if they are to provide sustainable solutions to the problems they cause.

The limitations of this study lie in the methodological approach for identifying sustainable business models in the manufacturing sector. This approach might exclude relevant information about identified models within other themes, languages, and publication types. Another limitation is that in the management field, terms are not as precise as in medicine or science, hence, themes for sustainable business models might hide under labels where we might not expect to find it. However, the purpose of this study was not to exhaust the understanding of the subject of sustainable business models, but to add a small contribution to the research done on sustainable business models, identifying current practices, possibilities, and challenges businesses face on the journey to a more sustainable business.

This paper proposes the consideration of more empirical studies investigating sustainability strategies of manufacturing companies. There is a clear gap in understanding how sustainable economic value is provided through repurposing for the society/environment, as well as developing scale-up solutions and inclusive value creation. 


\section{REFERENCES}

Aagaard, A. (2019). Sustainable business models: Innovation, implementation and success. London: Palgrave Macmillan

Adams, R., Jeanrenaud, S., Bessant, J., Denyer, D., \& Overy, P. (2016). Sustainability-oriented innovation: A systematic review. International Journal of Management Reviews, 18(2), 180-205. https://doi.org/10.1111/ijmr.12068

Anand, S., \& Sen, A. (2000). Human development and economic sustainability. World Development, 28(12), 2029-2049. https://doi.org/10.1016/S0305-750X(00)00071-1

Andersen, M. M. (2015, December). Frugal innovation and green business models. ISPIM Innovation Summit, Brisbane, Australia. Retrieved from https://orbit.dtu.dk/ en/publications/frugal-innovation-and-green-business$\underline{\text { models }}$

Bocken, N. M. P., Pauw, I. D., Bakker, C., \& Van Der Grinten, B. (2016). Product design and business model strategies for a circular economy. Journal of Industrial and Production Engineering, 33(5), 308-320. https://doi.org/10.1080/21681015.2016.1172124

Bocken, N. M. P., Short, S. W., Rana, P., \& Evans, S. (2014). A literature and practice review to develop sustainable business model archetypes. Journal of Cleaner Production, 65, 42-56. https://doi.org/10.1016/j.jclepro.2013.11.039

Bocken, N. M. P., Weissbrod, I., \& Tennant, M. (2016). Business model experimentation for sustainability. In R. Setchi, R. J. Howlett, Y. Liu, \& P. Theobald (Eds.), Sustainable Design and Manufacturing 2016. Berlin: Springer Science and Business Media Deutschland GmbH. https://doi.org/10.1007/978-3-319-32098-4_26

Bogers, M., Chesbrough, H., \& Strand, R. (2020). Sustainable open innovation to address a grand challenge: Lessons from Carlsberg and the green fiber bottle. British Food Journal, 122(5), 1505-1517. https://doi.org/10.1108/BFJ-07-2019-0534

Caldera, H.T.S., Desha, C., \& Dawes, L. (2017). Exploring the role of lean thinking in sustainable business practice: A systematic literature review. Journal of Cleaner Production, 167, 15461565. https://doi.org/10.1016/j.jclepro.2017.05.126

Carayannis, E. G., Sindakis, S., \& Walter, C. (2015). Business model innovation as lever of organizational sustainability. Journal of Technology Transfer, 40(1), 85-104. https://doi.org/10.1007/s10961-013-9330-y

Carroll, C., Booth, A., \& Cooper, K. (2011). A worked example of "best fit" framework synthesis: A systematic review of views concerning the taking of some potential chemopreventive agents. BMC Medical Research Methodology, 11(1), 29. https://doi.org/10.1186/1471-2288-11-29

Carroll, C., Booth, A., Leaviss, J., \& Rick, J. (2013). "Best fit" framework synthesis: Refining the method. BMC Medical Research Methodology, 13, 37. https://doi.org/10.1186/1471-2288-13-37

Casadesus-Masanell, R., \& Ricart, J. E. (2010). From strategy to business modelsandontotactics. LongRangePlanning, 43(23), 195-215. https://doi.org/10.1016/j.Irp.2010.01.004
Cioffi, R., Travaglioni, M., Piscitelli, G., Petrillo, A., \& Parmentola, A. (2020). Smart manufacturing systems and applied industrial technologies for a sustainable industry: A systematic literature review. Applied Sciences, 10(8), 2897. https://doi.org/10.3390/app10082897

Clinton, L., \& Whisnant, R. (2019). Business model innovations for sustainability. In G. G. Lenssen, \& N. C. Smith (Eds.), Managingsustainable business: An executiveeducation case and textbook (pp. 463-503). Amsterdam: Springer Netherlands. https://doi.org/10.1007/978-94-024-1144-7 22

Crals, E., \& Vereeck, L. (2004, February). Sustainable entrepreneurship in SMEs: Theory and practice. Proceedings of the global conference on environmental justice and global citizenship, Copenhagen, Denmark, 3. Retrieved from https://growthorientedsustainableentrepreneurship.files. wordpress.com/2016/07/en-sustainable-entrepreneurshipin-smes.pdf

Crowther, M. A., \& Cook, D. J. (2007). Trials and tribulations of systematic reviews and meta-analyses. hematology. Hematology ASH Education Program, 2007(1), 493-497. https://doi.org/10.1182/ASHEDUCATION-2007.1.493

Denyer, D., \& Tranfield, D. (2009). Producing a systematic literature review. In D. Buchanan \& A. Bryman (Eds.), The SAGE handbook of organizational research methods (pp. 671-689). Newbury Park, CA: Sage Publications.

Doganova, L., \& Eyquem-Renault, M. (2009). What do business models do? Innovation devices in technology entrepreneurship. Research Policy, 38(10), 1559-1570. https://doi.org/10.1016/j.respol.2009.08.002

Elkington, J. (1994). Towards the sustainable corporation: Winwin-win business strategies for sustainable development. California Management Review, 36(2), 90-100. https://doi.org/10.2307/41165746

Elkington, J. (1997). Cannibals with forks: The triple bottom line of 21 st century business. Mankato, MN: Capstone.

Elkington, J. (1998). Partnerships from cannibals with forks: The triple bottom line of 21 st-century business. Environmental Quality Management, 8(1), 37-51. https://doi.org/10.1002/tqem.3310080106

Esty, D. C., \& Winston, A. S. (2006). Green to gold: How smart companies use environmental strategy to innovate, create value, and build competitive advantage. Hoboken, NJ: Wiley.

Fargnoli, M., Costantino, F., Di Gravio, G., \& Tronci, M. (2018). Product service-systems implementation: A customized framework to enhance sustainability and customer satisfaction. Journal of Cleaner Production, 188, 387-401. https://doi.org/10.1016/j.jclepro.2018.03.315

Fisher, A. G. B. (1945). Economic progress and social security. London: Macmillan and Company.

Freudenreich, B., Lüdeke-Freund, F., \& Schaltegger, S. (2020). A stakeholder theory perspective on business models: Value creation for sustainability. Journal of Business Ethics, 166, 3-18. https://doi.org/10.1007/s10551-019-04112-z 
García-Muiña, F. E., Medina-Salgado, M. S., Ferrari, A. M., \& Cucchi, M. (2020). Sustainability transition in industry 4.0 and smart manufacturing with the triple-layered business model canvas. Sustainability, 12(6), 2364. https://doi.org/10.3390/su12062364

Garetti, M., \& Taisch, M. (2012). Sustainable manufacturing: Trends and research challenges. Production Planning and Control, 23(2-3), 83-104. https://doi.org/10.1080/09537287.2011.591619

Geibler, J. V., Liedtke, C., Wallbaum, H., \& Schaller, S. (2006). Accounting for the social dimension of sustainability: Experiences from the biotechnology industry. Business Strategy and the Environment, 15(5), 334-346. https://doi.org/10.1002/bse.540

González-Varona, J. M., Poza, D., Acebes, F., Villafáñez, F., Pajares, J., \& López-Paredes, A. (2020). New business models for sustainable spare parts logistics: A case study. Sustainability, 12(8), 3071. https://doi.org/10.3390/su12083071

Gupta, N., \& Benson, J. (2011). Sustainability and competitive advantage: An empirical study of value creation. Competition Forum, 9(1), 121-137. Retrieved from http:// papers.ssrn.com/sol3/papers.cfm?abstract $\mathrm{id}=2037493$

Hankammer, S., Jiang, R., Kleer, R., \& Schymanietz, M. (2018). Are modular and customizable smartphones the future, or doomed to fail? A case study on the introduction of sustainable consumer electronics. CIRP Journal of Manufacturing Science and Technology, 23, 146-155. https://doi.org/10.1016/j.cirpj.2017.11.001

Hazarika, A. (2015). History and significance of CSR and social audit in business: Setting a regulatory framework. In M. M. Rahim, \& S. O. Idowu (Eds.), Social audit regulation: Development, challenges and opportunities (pp. 217-256). Cham, Switzerland: Springer, Cham. https://doi.org/10.1007/978-3-319-15838-9 12

Hogevold, N. M., \& Svensson, G. (2012). A business sustainability model: A European case study. Journal of Business or Industrial Marketing, 27(2), 142-151. https://doi.org/10.1108/08858621211197001

Homrich, A. S., Theodoro, D. S., \& Carvalho, M. M. (2017). PSS creating business for sustainability: The Brazilian olive oil case in Mantiqueira community. Procedia CIRP, 64, 405410. https://doi.org/10.1016/j.procir.2017.03.110

Jacques, J. J., Agogino, A. M., \& Guimaraes, L. B. M. (2010, August). Sustainable product development initiatives in the footwear industry based on the cradle to cradle concept. Proceedings of the ASME Design Engineering Technical Conference (pp. 473-481), Montreal, Canada, 6. https://doi.org/10.1115/DETC2010-29061

Jiao, N., \& Evans, S. (2017). Business models for sustainability: The case of repurposing a second-life for electric vehicle batteries. In G. Campana, R. J. Howlett, R. Setchi, \& B. Cimatti (Eds.), Sustainable Design and Manufacturing 2017 (pp. 537-545.) Cham, Swtizerland: Springer, Cham.

Joyce, A., \& Paquin, R. L. (2016). The triple layered business model canvas: A tool to design more sustainable business models. Journal of Cleaner Production, 135, 1474-1486. https://doi.org/10.1016/j.jclepro.2016.06.067
Kemp, R., \& Andersen, M. (2004). Strategies for eco-efficiency innovation. IMR strategielijnen project voor VROM. Maastricht Economic Research Institute on Innovation and Technology, Maastricht, Netherlands.

Kiel, D., Muller, J. M., Arnold, C., \& Voigt, K.-I. (2017). Sustainable industrial value creation: Benefits and challenges of industry 4.0. International Journal of Innovation Management, 21(8), 1740015. https://doi.org/10.1142/S1363919617400151

Kravchenko, M., Pigosso, D. C., \& McAloone, T. C. (2019). Towards the ex-ante sustainability screening of circular economy initiatives in manufacturing companies: Consolidation of leading sustainability-related performance indicators. Journal of Cleaner Production, 241, 118318. https://doi.org/10.1016/j.jclepro.2019.118318

Li, X., Cao, J., Liu, Z., \& Luo, X. (2020). Sustainable business model based on digital twin platform network: The inspiration from haier's case study in China. Sustainability, 12(3), 936. https://doi.org/10.3390/su12030936

Lin, Y., Li, J., Huang, X., Guo, Z., Sun, Y., \& Zhang, R. (2018). Exploring a sustainable business routing for China's new energy vehicles: BYD as an example. In K. Li, J. Zhang, M. Chen, Z. Yang, \& Q. Niu (Eds.), Advances in green energy systems and smart grid. Singapore: Springer Singapore.

Lindstrom, J. (2016). When moving from products and services towards functional products: Which sustainabilityoriented customer values are of interest? Procedia CIRP, 48, 16-21. https://doi.org/10.1016/j.procir.2016.03.027

Lüdeke- Freund, F. (2010, October). Towards a conceptual framework of business models for sustainability. Proceedings of the Knowledge collaboration \& learning for sustainable innovation ERSCP-EMSU Conference, Delft, Netherlands, 49. https://doi.org/10.13140/RG.2.1.2565.0324

Lyytinen, T. (2017). Sustainable business models of small-scale renewable energy systems: Two resource-scarce approaches for design and manufacturing. In G. Campana, R. J. Howlett, R. Setchi, \& B. Cimatti (Eds.), Sustainable Design and Manufacturing 2017 (pp. 493-504). Cham, Swtizerland: Springer, Cham.

Maçaneiro, M. B., \& Cunha, S. K. (2014). Contextual factors as drivers of eco-innovation strategies. In S. G. Azevedo, M. Brandenburg, H. Carvalho, \& V. Cruz-Machado (Eds.), Eco-innovation and the development of business models (pp. 137-162). Cham, Swtizerland: Springer, Cham. https://doi.org/10.1007/978-3-319-05077-5_8

Magretta, J. (2002). Why business models matter. Harvard Business Review, 80(5), 86-92. Retrieved from https://hbr.org/2002/05/why-business-models-matter

Marcus, A. (2018). The role of human resource management (HRM) for the implementation of sustainable product-service systems (PSS) - An analysis of fashion retailers. Sustainability, 10(7), 2518. https://doi.org/10.3390/su10072518

Massa, L., Tucci, C. L., \& Afuah, A. (2017). A critical assessment of business model research. Academy of Management Annals, 11(1). https://doi.org/10.5465/annals.2014.0072 
McLennan, S., \& Banks, G. (2019). Reversing the lens: Why corporate social responsibility is not community development. Corporate Social Responsibility and Environmental Management, 26(1), 117-126. https://doi.org/10.1002/csr.1664

Moratis, L., Melissen, F., \& Idowu, S. O. (2018). Sustainable business models: Principles, promise, and practice. Cham, Swtizerland: Springer, Cham. https://doi.org/10.1007/978-3-319-73503-0

Pacheco, D. A. J., Caten, C. S. T., Jung, C. F., Sassanelli, C., \& Terzi, S. (2019). Overcoming barriers towards sustainable product-service systems in small and mediumsized enterprises: State of the art and a novel decision matrix. Journal of Cleaner Production, 222, 903-921. https://doi.org/10.1016/j.jclepro.2019.01.152

Pinna, C., Demartini, M., Tonelli, F., \& Terzi, S. (2018). How soft drink supply chains drive sustainability: Key performance indicators (KPIs) identification. Procedia CIRP, 72, 862867. https://doi.org/10.1016/j.procir.2018.04.008

Pojasek, R. B. (2012). Implementing a sustainability management system. Environmental Quality Management, 22(1), 8390. https://doi.org/10.1002/tqem.21319

Porter, M. E., \& Van Der Linde, C. (1995). Green and competitive: Ending the stalemate. Harvard Business Review, 73(5). Retrieved from https://hbsp.harvard.edu/product/95507-PDF-ENG

Rajala, R., Westerlund, M., \& Lampikoski, T. (2016). Environmental sustainability in industrial manufacturing: Re-examining the greening of interface's business model. Journal of Cleaner Production, 115, 52-61. https://doi.org/10.1016/j.jclepro.2015.12.057

Reim, W., Lenka, S., Frishammar, J., \& Parida, V. (2017). Implementing sustainable product-service systems utilizing business model activities. Procedia CIRP, 64, 6166. https://doi.org/10.1016/j.procir.2017.03.130

Ritala, P., Huotari, P., Bocken, N., Albareda, L., \& Puumalainen, K. (2018). Sustainable business model adoption among S\&P 500 firms: A longitudinal content analysis study. Journal of Cleaner Production, 170, 216-226. https://doi.org/10.1016/j.jclepro.2017.09.159

Stubbs, W., \& Cocklin, C. (2008). Conceptualizing a "sustainability business model." Organization and Environment, 21(2), 103-127. https://doi.org/10.1177/1086026608318042
Teece, D. J. (2010). Business models, business strategy and innovation. Long Range Planning, 43(2-3), 172-194. https://doi.org/10.1016/J.LRP.2009.07.003

Thorpe, R., Holt, R., Macpherson, A., \& Pittaway, L. (2005). Using knowledge within small and medium-sized firms: A systematic review of the evidence. International Journal of Management Reviews, 7(4), 257-281. https://doi.org/10.1111/j.1468-2370.2005.00116.x

Tonelli, F., Evans, S., \& Taticchi, P. (2013). Industrial sustainability: Challenges, perspectives, actions. International Journal of Business Innovation and Research, 7(2), 143-163. Retrieved from http://www.inderscience.com/offer.php?id=52576

Tranfield, D., Denyer, D., \& Smart, P. (2003). Towards a methodology for developing evidence-informed management knowledge by means of systematic review. British Journal of Management, 14(3), 207-222. https://doi.org/10.1111/1467-8551.00375

Wanniarachchi, T., Dissanayake, K., \& Downs, C. (2020). Improving sustainability and encouraging innovation in traditional craft sectors: The case of the Sri Lankan handloom industry. Research Journal of Textile and Apparel, 24(2), 111-130. https://doi.org/10.1108/RJTA-09-2019-0041

Willard, B. (2005). The next sustainability wave: Building boardroom buy-in. Gabriola, Canada: New Society Publishers.

World Commission on Environment and Development. (1987). Our common future (the Brundtland comission report). Oxford: Oxford University Press. Retrieved from https://sustainabledevelopment.un.org/content/ documents/5987our-common-future.pdf

Yang, M., Evans, S., Vladimirova, D., \& Rana, P. (2017). Value uncaptured perspective for sustainable business model innovation. Journal of Cleaner Production, 140, 17941804. https://doi.org/10.1016/j.jclepro.2016.07.102

Yunus, M., Moingeon, B., \& Lehmann-Ortega, L. (2010). Building social business models: Lessons from the grameen experience. Long Range Planning, 43(2-3), 308-325. https://doi.org/10.1016/j.lrp.2009.12.005

Zott, C., Amit, R., \& Massa, L. (2011). The business model: Recent developments and future research. Journal of Management, 37(4), 1019-1042. https://doi.org/10.1177/0149206311406265

Zott, C., \& Amit, R. (2013). The business model: A theoretically anchored robust construct for strategic analysis. Strategic Organization, 11(4), 403-411. https://doi.org/10.1177/1476127013510466 


\section{Authorship}

\section{Ukeje Jacob Agwu*}

UiT The Arctic University of Norway, School of Business and Economics

Breivangvegen 23, 9010 Tromsø, Norway

E-mail address: ukeje.j.agwu@uit.no

(1) https://orcid.org/0000-0003-4842-6812

\section{John Bessant}

University of Stavanger, Centre for Innovation Research

PO box 8600 Forus 4036 Stavanger, Norway

E-mail address: johnrbessant@gmail.com

(1) https://orcid.org/0000-0002-5040-4949

* Corresponding Author

\section{Funding}

There are no funders to report for this article.

\section{Conflict of Interests}

The authors have stated that there is no conflict of interest.

\section{Copyrights}

RAC owns the copyright to this content.

\section{Plagiarism Check}

The RAC maintains the practice of submitting all documents approved for publication to the plagiarism check, using specific tools, e.g.: iThenticate.

\section{Authors' Contributions}

$1^{\text {st }}$ author: conceptualization (equal); data curation (lead); formal analysis (lead); investigation (lead); methodology (equal); visualization (equal); writing-original draft (lead); writing-review \& editing (lead).

$2^{\text {nd }}$ author: conceptualization (equal); formal analysis (supporting); methodology (equal); supervision (lead); validation (lead); visualization (supporting).

\section{Peer Review Method}

This content was evaluated using the double-blind peer review process. The disclosure of the reviewers' information on the first page, as well as the Peer Review Report, is made only after concluding the evaluation process, and with the voluntary consent of the respective reviewers and authors.

\section{Data Availability}

All data and materials were made publicly available through the Mendeley platform and can be accessed at:

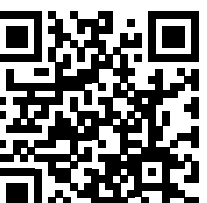

Ukeje Jacob Agwu; John Bessant, 2021, "Replication Data for: "Sustainable Business Models: A Systematic Review of Approaches and Challenges in Manufacturing" published by the Journal of Contemporary Administration", Harvard Dataverse, V1. https://doi.org/10.7910/DVN/5DYU3N

RAC encourages data sharing but, in compliance with ethical principles, it does not demand the disclosure of any means of identifying research subjects, preserving the privacy of research subjects. The practice of open data is to enable the reproducibility of results, and to ensure the unrestricted transparency of the results of the published research, without requiring the identity of research subjects. 


\section{APPENDIX A}
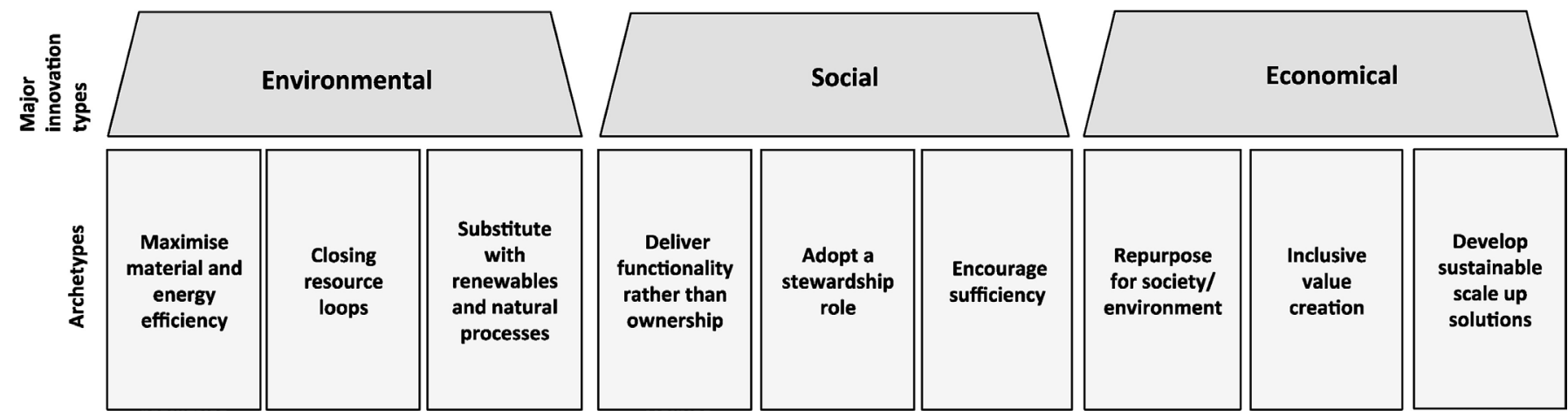

Figure A1. Archetypes for classification of the empirical literature.

Source: Ritala, P., Huotari, P., Bocken, N., Albareda, L., \& Puumalainen, K. (2018). Sustainable business model adoption among S\&P 500 firms: A longitudinal content analysis study. Journal of Cleaner Production, 170, 216-226. https://doi.org/10.1016/j.jclepro.2017.09.159

1. Maximize material and energy efficiency includes:
a. Low-carbon manufacturing/solutions
b. Lean manufacturing
c. Dematerialization of products/packaging
d. Increased functionality

2. Closing resource loops includes:
a. Circular economy/closed loop
b. Cradle-to-cradle
c. Industrial symbiosis
d. Reuse, recycle, remanufacture
e. Take-back management

3. Substitute with renewables and natural processes includes:

a. Move from non-renewable to renewable energy sources

b. Innovations in solar and wind energy

c. Zero emissions initiative

d. Slow manufacturing

4. Deliver functionality rather than ownership includes:

a. Product-oriented PSS - maintenance, extended warrantee

b. Use-oriented PSS - rental, lease, shared

c. Result-oriented PSS - pay per use

5. Adopt a stewardship role includes:
a. Biodiversity protection
b. Consumer care
c. Ethical trade
d. Choice editing by retailers

e. Radical transparency about environmental/societal impacts

6. Encourage sufficiency includes:

a. Consumer education, communication

b. Demand management

c. Slow fashion

d. Product longevity

e. Premium branding/limited availability

f. Frugal business

7. Repurpose for society/environment includes:

a. Not for profit

b. Hybrid business/social enterprise (for profit)

c. Alternative ownership, mutual collectives, cooperatives

$\mathrm{d}$. Social and biodiversity regeneration initiatives

8. Inclusive value creation includes:

a. Collaborative approaches

b. Peer to peer, sharing

c. Inclusive innovation

d. Bottom of pyramid solutions

9. Develop sustainable scale-up solutions includes:

a. Incubator and entrepreneur support models

b. Open innovation

c. Patient/slow capital

d. Impact investing/capital

e. Crowd sourcing

f. Peer to peer, lending 


\section{APPENDIX B}

Table B1. Full list of analyzed papers.

\begin{tabular}{|c|c|c|}
\hline Research Author(s) & Source & Research Method \\
\hline González-Varona et al. (2020) & Sustainability & Experiments \\
\hline Li et al. (2020) & Sustainability & Interviews, informal discussions, and field visits \\
\hline Marcus (2018) & Sustainability & Questionnaires \\
\hline García-Muińa et al (2020) & Sustainability & Interviews \\
\hline Yang et al (2017) & Journal of Cleaner Production & Interviews and workshops \\
\hline Fargnoli et al. (2018) & Journal of Cleaner Production & Questionnaires and interviews \\
\hline Rajala et al. (2016) & Journal of Cleaner Production & Interviews \\
\hline Homrich et al. (2017) & Procedia CIRP & Interviews \\
\hline Pinna et al. (2018) & Procedia CIRP & Interviews and questionnaires \\
\hline Reim et al. (2017) & Procedia CIRP & Interviews \\
\hline Lindstrom (2016) & Procedia CIRP & Interviews \\
\hline Jiao and Evans (2017) & Procedia CIRP & Interviews \\
\hline Wanniarachchi et al. (2020) & Research Journal of Textile and Apparel & Interviews and observations \\
\hline Jacques et al. (2010) & $\begin{array}{l}\text { Proceedings of the ASME Design Engineering } \\
\text { Technical Conference }\end{array}$ & Interviews \\
\hline Kiel et al. (2017) & International Journal of Innovation Management & Interviews \\
\hline Bogers et al. (2020) & British Food Journal & Interviews \\
\hline Hogevold and Svensson (2012) & Journal of Business \& Industrial Marketing & Interviews, observations, and document analysis \\
\hline Lyytinen (2017) & Smart Innovation, Systems and Technologies & Interviews \\
\hline Lin et al. (2018) & $\begin{array}{l}\text { Communications in Computer and Information } \\
\text { Science }\end{array}$ & Interviews \\
\hline Carayannis et al (2015) & Journal of Technology Transfer & Interviews \\
\hline Hankammer et al. (2018) & $\begin{array}{l}\text { CIRP Journal of Manufacturing Science and } \\
\text { Technology }\end{array}$ & Interviews \\
\hline
\end{tabular}

Manufacture of electrical equipment

Manufacture of motor vehicles, trailers and semi-trailers

Manufacture of computer, electronic and optical products

Manufacture of machinery and equipment n.e.c.

Manufacture of textiles

Manufacture of furniture

Manufacture of beverages

Manufacture of wearing apparel

Manufacture of other non-metallic mineral products

Manufacture of food products

Manufacture of leather and related products

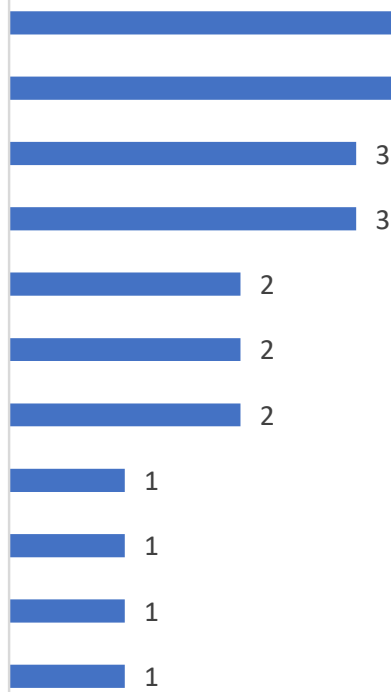

Figure B1. Selected studies by division in the ISIC manual (some studies investigate more than one division; hence, focus of studies might overlap. 